\title{
TINDAKAN PERAWAT DALAM MENINGKATKAN PENERAPAN K3 DI RUMAH SAKIT
}

\author{
JIHAN ASYLA
}

Jihanasyla20@gmail.com

\begin{abstract}
ABSTRAK
Latar belakang : Selain menjalankan dan memberikan asuhan keperawatan, keselamatan pasien, perawat juga berkewajiban untuk memiliki pengetahuan mengenai K3 Di rumah sakit. Untuk memenuhi kebutuhan rasa aman dan nyaman saat berkerja di rumah sakit, perawat harus melaukan tindakan k3 di rumah sakit.

Tujuan : untuk menjelaskan tindakan perawat dalam menerapkan keselamatan kerja ngetahui hal yang dapat meningkatan pemahaman perawat dalam menjalankan/ menerapkan sistem keselamatan pasien di rumah sakit dalam memberikan asuhan keperawatan.

Metode : pengkajian ini menggunakan metode kualitatif, yang dimana metode ini lebih cenderung menonjolkan bersifat subjektif dimana proses penelitian ini lebih memperlihatkan dan cenderung lebih focus pada landasan teori yang dikutip

Hasil : Perawat dapat melakukan tindakan untuk meningkatkan penerapan k3 di rumah sakit yaitu dengan melakukan tahap tindakannya, tindakan program K3Rs

Kesimpulan : Perawat dalam melaksanakan tugasnya di rumah sakit harus memiliki pengetahuan yang cukup untuk memenerapkan serta menjalakan $\mathrm{k} 3$ di rumah sakit. Untuk meningkatkan dan memenuhi rasa aman dan nyaman pada saat berada di tempat kerja. kesehatan dan keselamatan berkaitan dengan tenaga kerja, pekerjaan dan lingkungan kerja, yang meliputi segala upaya untuk mencegah dan menanggulangi segala sakit dan kecelakaan akibat kerja.
\end{abstract}

\section{Kata Kunci : penerapan tindakan K3, Perawat, Rumah Sakit.}




\section{PENDAHULUAN}

Keselamatan pasien adalah suatu system yang membuat asuhan pasien lebih aman, serta implementasi solusi untuk meminimalkan timbulnya resiko dan mencegah terjadinya cedera yang disebabkan oleh kesalahan akibat melaksanakan suatu tindakan atau tidak mengambil tindakan yang seharusnya diambil (Menteri Kesehatan RI, 2017).

Selain menjalankan keselamatan pasien, perawat juga berkewajiban untuk memiliki pengetahuan mengenai K3 Di rumah sakit,

Menurut Hughes (2008),perawat merupakan kunci dalam pengembangan mutu melalui keselamatan pasien. Perawat merupakan unsur vital dalam sebuah Rumah Sakit karena perawat merupakan penjalin kontak pertama dan terlama dengan pasien khususnya pasien rawat inap, dengan tugas utama perawat adalah memberikan asuhan keperawatan dari pengkajian, penegakan diagnosa, keperawatan, intervensi, implementasi sampai dengan evaluasi (Potter \& Perry, 2009).

Menurut penelitian cohyono (2015), Tenaga perawat merupakan tenaga profesional yang berperan penting dalam fungsi rumah sakit. Hal tersebut didasarkan atas jumlah tenaga perawat sebagai porsi terbesar didalam pelayanan rumah sakit. perawat sebagai komponen yang penting dalam pelaporan kesalahan pelayanan dalam pengembangan program keselamatan pasien di rumah sakit. Namun masih ada perawat yang tidak menerapkan dan menjaga keselamatan pasien sehingga angka terjadinya kecelakaan pasien semakin meningkat.

\section{TUJUAN}

Tujuan dari penulisan kajian ini yaitu untuk menjelaskan tindakan perawat dalam menerapkan keselamatan kerja ngetahui hal yang dapat meningkatan pemahaman perawat dalam menjalankan/ menerapkan sistem keselamatan pasien di rumah sakit dalam memberikan asuhan keperawatan.

\section{METODE}

Pada pengkajian ini digunakan metode kualitatif, yang dimana metode ini lebih cenderung menonjolkan bersifat subjektif dimana proses penelitian ini lebih memperlihatkan dan cenderung lebih focus pada landasan teori yang dikutip dari leterature review serta memberikan penjelasan.

\section{HASIL}

Hasil dari pengkajian ini yaitu ; Perawat dapat melakukan tindakan untuk meningkatkan penerapan $\mathrm{k} 3$ di rumah sakit 
yaitu dengan melakukan tahap tindakannya, tindakan program K3Rs yaitu; pelaksanaan kesehatan kerja bagi karyawan (pekerja, berkala, dan khusus), upaya mengamankan pasien (menjalankan sistem keselamatan pasien), sanitasi lingkungan RS, pengelolaan dan pengolahan limbah padat, cair, gas.

\section{PEMBAHASAN}

Dalam pelaksanaan Kesehatan dan Keselamatan Kerja (K3) di rumah sakit. K3 merupakan bentuk untuk menciptakan tempat kerja yang aman, sehat, bebas dari pencemaran lingkungan, sehingga dapat mengurangi dan bebas dari kecelakaan kerja maupun penyakit akibat kerja yang pada akhirnya meningkatkan efisiensi dan produktivitas kerja di rumah sakit.

Menurut Undang-Undang No 36 (2009), upaya Kesehatan dan Keselamatan Kerja (K3) harus dan dapat diselenggarakan di semua tempat kerja, khususnya tempat kerja yang mempunyai risiko bahaya kesehatan, mudah terjangkit penyakit atau mempunyai karyawan paling sedikit 10 orang.

Perawat dapat melakukan tindakan untuk meningkatkan penerapan $\mathrm{k} 3$ di rumah sakit yaitu dengan melakukan tahap tindakannya, tindakan program K3Rs yaitu; pelaksanaan kesehatan kerja bagi karyawan (pekerja, berkala, dan khusus), upaya mengamankan pasien (menjalankan sistem keselamatan pasien), sanitasi lingkungan RS, pengelolaan dan pengolahan limbah padat, cair, gas.

Pencegahan dan penanggulangan bencara, pengelolaan jasa, bahan dan barang berbahaya, memperkuat pengetahuan dan pendidikan serta pelatihan mengenai $\mathrm{K} 3$, sertifikasi dan kalibrasi sarana, prasarana, dan peralatan RS, Pengumpulan, pengolahan dan pelaporan $\mathrm{K} 3$.

\section{KESIMPULAN}

Perawat dalam melaksanakan tugasnya di rumah sakit harus memiliki pengetahuan yang cukup untuk memenerapkan serta menjalakan k3 di rumah sakit. Untuk meningkatkan dan memenuhi rasa aman dan nyaman pada saat berada di tempat kerja. kesehatan dan keselamatan berkaitan dengan tenaga kerja, pekerjaan dan lingkungan kerja, yang meliputi segala upaya untuk mencegah dan menanggulangi segala sakit dan kecelakaan akibat kerja.

\section{DAFTAR PUSTAKA}

Cahyono, Agung. (2015). Hubungan Karakteristik dan Tingkat Pengetahuan Perawat Terhadap Pengelolaan Keselamatan Pasien Di Rumah Sakit. 
Jurnal Ilmiah WIDYA. Volume 3 ( 2), 97 99

Depkes RI. (2011). Panduan Nasional Keselamatan Pasien Rumah Sakit. Jakarta : Depkes RI

Depkes RI. (2009). Undang- Undang Republik Indonesia No 36 Tahun 2009 Tentang Kesehatan. Jakarta: Kementerian Kesehatan RI.

Henriksen \& Dayto, E. (2006). Issues in the design of training for Quality and safety. Quality and safery health care 15 (1), 117124.

Hughes, R. G. (2008). Patient Safety and Quality : An Evidence Based Handbook For Nurses, Agency For Healtycare Research and Quality. Gaither Road Rockville, MD 20850

Kementerian Kesehatan RI. (2011). Permenkes RI. Nomor 1691 Tahun 2011 Tentang Keselamatan Pasien Rumah Sakit,. Jakarta,: Kementerian Kesehatan RI

Kementerian Kesehatan RI. (2017). Peraturan Menteri Kesehatan Republik Indonesia Nomor 11 Tahun 2017 Tentang Keselamatan Pasien. Jakarta : Kementerian Kesehatan RI.
Kementerian Kesehatan Republik Indonesia. (2013). Panduan Keselamatan Pasien. Jakarta : Kementerian Kesehatan Republik Indonesia.

KKP-RS. (2007). Pedoman Pelaporan Keselamatan Pasien. Jakarta : KKP-RS

Simamora, R. H. (2019 November 08). Pengaruh Penyuluhan Identifikasi Pasien dengan Menggunakan Media Audiovisual Terhadap Pengetahuan Pasien Rawat Inap. Jurnal Keperawatan Silampari, 342-251.

Simamora, R. H. (2019). Buku Ajar : Pelaksanaan Identifikasi Pasien. Ponorogo, Jawam Timur : Uwais Inspirasi Indonesia.

Simamora, R. H. (2019). Documentation of Patient Identification into the Electronic System To Improve The Quality of Nursing ServicesInternational. Journal of Scientific \& Technology Research. 8((), 1884-1886

Potter \& Perry. (2009). Fundamental Keperawatan. Edisi 7. Jakarta : Salemba Medika 